\title{
GAMBARAN PENGETAHUAN IBU HAMIL TENTANG PENTINGNYA MELINDUNGI DIRI DALAM MASA AKB (ADAPTASI KEBIASAAN BARU) DI ERA NEW NORMAL COVID-19 BERDASARKAN SUMBER INFORMASI DI POSYANDU MAWAR DESA SUKAHARJA 2021
}

\author{
Aina Awaliah, Dewi Laelatul Badriah, Nova Winda Setiati \\ STIKes Kuningan \\ ainaawaliah736@gmail.com
}

\begin{abstract}
Abstrak
Ibu hamil tercatat salah satu kelompok rentan risiko terinfeksi covid-19 dikarenakan pada masa kehamilan terjadinya perubahan fisiologi yang mengakibatkan penurunan kekebalan parsial. Data sebaran covid-19 pada 30 Januari 2021 di Kabupaten Kuningan menyebutkan bahwa kasus covid-19 di Kabupaten Kuningan jumlahnya yaitu sebanyak 339 pasien positif yang sedang melakukan karantina, total penderita yang sembuh yaitu sebanyak 2379 jiwa, dan kasus meninggal dunianya sebanyak 52 orang. Tujuan penelitian ini untuk mengetahui gambaran pengetahuan ibu hamil tentang pentingnya melindungi diri dalam masa AKB di era new normal covid-19 berdasarkan sumber informasi di Posyandu Mawar Desa Sukaharja 2021. Jenis penelitian ini deskriptif dengan rancangan observasional. Populasi dalam penelitian ini yaitu ibu hamil di Desa Sukaharja, teknik pengambilan sampling menggunakan teknik total sampling yaitu seluruh ibu hamil yang berjumlah 30 orang. Instrument yang digunakan dengan menggunakan kuesioner dan lembar checklist dan analisis data menggunakan analisis univariat. Hasil penelitian diketahui bahwa dari 30 ibu hamil sebagian besar memiliki pengetahuan baik sebanyak 17 orang $(56,7 \%)$, sebagian besar ibu hamil mendapatkan informasi televisi melalui berita sebanyak 18 orang (60\%), sedangkan yang memiliki pengetahuan dari sumber informasi internet facebook sebanyak 17 orang (56,7\%), ibu hamil yang memiliki pengetahuan dari sumber informasi tenaga kesehatan bidan yaitu 14 orang $(46,7 \%)$, dan yang memiliki pengetahuan dari sumber informasi keluarga yaitu suami sebanyak 19 orang $(63,3 \%)$.
\end{abstract}

Kata Kunci: Pengetahuan, Covid-19, Ibu hamil, Sumber informasi 
JOURNAL OF MIDWIFERY CARE :

VOL. 02 No. 01, DESEMBER 2021

DOI : $\underline{10.34305 / J M C . V 2 I 01.346}$

\section{Pendahuluan}

Coronavirus adalah keluarga besar virus yang menyebabkan penyakit mulai dari gejala ringan sampai berat. Bertepatan pada tanggal 31 Januari 2021 jumlah kasus Covid-19 di seluruh dunia sebanyak 103jt jiwa terkonfirmasi positif sebanyak 56,7jt dan kasus meninggal dunia sebanyak 2,22jt. Indonesia mendapati jumlah kasus konfirmasi positif sebanyak 1,05jt jiwa, dan 852rb jiwa sudah dinyatakan sembuh, sedangkan kasus meninggal dunianya sebanyak 29.518 jiwa. Di Jawa Barat terdapat $147 \mathrm{rb}$ jiwa yang terkonfirmasi positif covid-19, dengan kasus sembuhnya sebanyak 115rb, dan 29.518 jiwa dinyatakan meninggal dunia, Kabupaten Kuningan sebanyak 339 pasien positif yang sedang melakukan karantina, total penderita yang sembuh yaitu sebanyak 2379 jiwa, dan kasus meninggal dunianya sebanyak 52 orang (Komite Penanganan Covid-19, 2020).

Januari 2020 WHO melaporkan bahwa wanita hamil rentan terhadap infeksi SARS-CoV-2 yang dapat meningkatkan risiko yang merugikan pada ibu hamil. Ditemukan 3 laporan kasus serial, dengan total 31 kehamilan yang dengan COVID-19 sebagai penyerta.
Ciptaan disebarluaskan di bawah

Lisensi Creative Commons Atribusi-

NonKomersial-BerbagiSerupa 4.0 Internasional

Sumber informasi merupakan sesuatu yang penting bagi seseorang untuk menentukan sikap atau keputusan bertindak. Hasil wawancara peneliti kepada salah satu anggota Pemdes Sukaharja didapati bahwa Desa Sukaharja juga termasuk desa yang warganya pernah terinfeksi covid-19 yakni sebanyak 3 orang, kasus PDP 10 orang dan ODP sebanyak 237 orang.

Berdasarkan studi pendahuluan kepada $10 \mathrm{ibu}$ hamil di Desa Sukaharja dengan hasil 6 orang ibu hamil masih kurang mengerti tentang bagaimana cara melindungi diri dalam masa $\mathrm{AKB}$ dan 4 orang ibu hamil sudah mengerti tentang bagaimana cara melindungi diri di masa AKB dan menerapkan hal-hal yang harus dilakukan sesuai anjuran pemerintah walaupun belum begitu merinci.

\section{Metode}

Jenis penelitian yang digunakan adalah deskriftif. Dilakukan di Posyandu Mawar Desa Sukaharja Kecamatan Cibingbin pada bulan Februari-April tahun 2021. Populasi dalam penelitian ini adalah ibu hamil di Desa Sukaharja yang berjumlah 30 orang.orang dengan teknik total sampling, instrument yang digunakan 
Hasil

Tabel 1. Distribusi Frekuensi Pengetahuan, Sumber Informasi Televisi, Sumber Informasi, Sumber Informasi Internet, Sumber Informasi Internet Keluarga Ibu hamil Posyandu Mawar Desa Sukaharja Kecamatan Cibingbin Tahun 2021

\begin{tabular}{|c|c|c|}
\hline Variabel & Frekuensi & Presentase $(\%)$ \\
\hline Total & 30 & 100 \\
\hline \multicolumn{3}{|c|}{ Pengetahuan } \\
\hline Baik & 17 & 56,7 \\
\hline Cukup & 12 & 40,0 \\
\hline Kurang & 1 & 3,3 \\
\hline \multicolumn{3}{|c|}{ Sumber Informasi Televisi } \\
\hline Berita & 18 & 60,0 \\
\hline Film & 7 & 23,3 \\
\hline Iklan & 5 & 16.7 \\
\hline \multicolumn{3}{|c|}{ Sumber Informasi } \\
\hline Instagram & 8 & 26,7 \\
\hline Facebook & 17 & 56,7 \\
\hline Twitter & 5 & 16,6 \\
\hline \multicolumn{3}{|c|}{ Sumber Informasi } \\
\hline Dokter & 12 & 40,0 \\
\hline Perawat & 4 & 13,3 \\
\hline Bidan & 14 & 46,7 \\
\hline \multicolumn{3}{|c|}{ Sumber Informasi } \\
\hline Suami & 19 & 63,3 \\
\hline Orangtua & 9 & 30.0 \\
\hline Saudara & 2 & 6,7 \\
\hline
\end{tabular}

Tabel 2. Gambaran Pengetahuan Ibu Hamil Tentang Pentingnya Melindungi Diri Dalam Masa AKB di Era New normal Covid-19 Berdasarkan Sumber Informasi Televisi di Posyandu Mawar Desa Sukaharja 2021 


\begin{tabular}{|c|c|c|c|c|c|c|c|c|}
\hline \multirow{3}{*}{$\begin{array}{c}\text { Sumber Informasi } \\
\text { Televisi }\end{array}$} & \multicolumn{6}{|c|}{ Pengetahuan } & \multirow{2}{*}{\multicolumn{2}{|c|}{ Total }} \\
\hline & \multicolumn{2}{|c|}{ Baik } & \multicolumn{2}{|c|}{ Cukup } & \multicolumn{2}{|c|}{ Kurang } & & \\
\hline & $\mathbf{F}$ & $\%$ & $\mathbf{F}$ & $\%$ & $\mathbf{F}$ & $\%$ & $\mathbf{F}$ & $\%$ \\
\hline Berita & 15 & 83,3 & 3 & 16,7 & 0 & 0,0 & 18 & 100 \\
\hline Film & 6 & 85,7 & 0 & 0,0 & 1 & 14,3 & 7 & 100 \\
\hline Iklan & 3 & 60,0 & 2 & 40,0 & 0 & 0,0 & 5 & 100 \\
\hline
\end{tabular}

Tabel 3. Gambaran Pengetahuan Ibu Hamil Tentang Pentingnya Melindungi Diri Dalam Masa AKB di Era New normal Covid-19 Berdasarkan Sumber Informasi Internet di Posyandu Mawar Desa Sukaharja 2021

\begin{tabular}{|c|c|c|c|c|c|c|c|c|}
\hline \multirow{3}{*}{$\begin{array}{c}\text { Sumber Informasi } \\
\text { Internet }\end{array}$} & \multicolumn{6}{|c|}{ Pengetahuan } & \multirow{2}{*}{\multicolumn{2}{|c|}{ Total }} \\
\hline & \multicolumn{2}{|c|}{ Baik } & \multicolumn{2}{|c|}{ Cukup } & \multicolumn{2}{|c|}{ Kurang } & & \\
\hline & $\mathbf{F}$ & $\%$ & $\mathbf{F}$ & $\%$ & $\mathbf{F}$ & $\%$ & $\mathbf{F}$ & $\%$ \\
\hline Instagram & 7 & 87,5 & 1 & 12,5 & 0 & 0,0 & 8 & 100 \\
\hline Facebook & 13 & 76,5 & 3 & 17,6 & 1 & 5,9 & 17 & 100 \\
\hline Twitter & 4 & 80,0 & 1 & 20,0 & 0 & 0,0 & 5 & 100 \\
\hline
\end{tabular}

Tabel 4. Gambaran Pengetahuan Ibu Hamil Tentang Pentingnya Melindungi Diri Dalam Masa AKB di Era New normal Covid-19 Berdasarkan Sumber Informasi Tenaga Kesehatan di Posyandu Mawar Desa Sukaharja 2021

\begin{tabular}{|c|c|c|c|c|c|c|c|c|}
\hline \multirow{3}{*}{$\begin{array}{l}\text { Sumber Informasi } \\
\text { Tenaga Kesehatan }\end{array}$} & \multicolumn{6}{|c|}{ Pengetahuan } & \multirow{2}{*}{\multicolumn{2}{|c|}{ Total }} \\
\hline & \multicolumn{2}{|c|}{ Baik } & \multicolumn{2}{|c|}{ Cukup } & \multicolumn{2}{|c|}{ Kurang } & & \\
\hline & $\mathbf{F}$ & $\%$ & $\mathbf{F}$ & $\%$ & F & $\%$ & $\mathbf{F}$ & $\%$ \\
\hline Dokter & 11 & 91,7 & 1 & $8,3 \%$ & 0 & 0,0 & 12 & 100 \\
\hline Perawat & 1 & 25,0 & 3 & $75,0 \%$ & 0 & 0,0 & 4 & 100 \\
\hline Bidan & 12 & 85,8 & 1 & $7,1 \%$ & 1 & $7,1 \%$ & 14 & 100 \\
\hline
\end{tabular}


Tabel 5. Gambaran Pengetahuan Ibu Hamil Tentang Pentingnya Melindungi Diri Dalam Masa AKB di Era New normal Covid-19 Berdasarkan Sumber Informasi Keluarga di Posyandu Mawar Desa Sukaharja 2021

\begin{tabular}{|c|c|c|c|c|c|c|c|c|}
\hline \multirow{3}{*}{$\begin{array}{c}\text { Sumber Informasi } \\
\text { Keluarga }\end{array}$} & \multicolumn{6}{|c|}{ Pengetahuan } & \multirow{2}{*}{\multicolumn{2}{|c|}{ Total }} \\
\hline & \multicolumn{2}{|c|}{ Baik } & \multicolumn{2}{|c|}{ Cukup } & \multicolumn{2}{|c|}{ Kurang } & & \\
\hline & $\mathbf{F}$ & $\%$ & $\mathbf{F}$ & $\%$ & $\mathbf{F}$ & $\%$ & $\mathbf{F}$ & $\%$ \\
\hline Suami & 16 & 84,2 & 3 & 15,8 & 0 & 0,0 & 19 & 100 \\
\hline Orangtua & 6 & 66,7 & 2 & 22,2 & 1 & 11,1 & 9 & 100 \\
\hline Saudara & 2 & 100,0 & 0 & 0,0 & 0 & 0,0 & 2 & 100 \\
\hline
\end{tabular}

\section{Pembahasan}

Berdasarkan tabel 1 diketahui bahwa dari 30 ibu hamil sebagian besar memiliki pengetahuan baik sebanyak 17 orang $(56,7 \%)$, sebagian besar mendapatkan informasi dari televisi melalui berita sebanyak 18 orang $(60,0 \%)$, sebagian besar mendapatkan informasi dari internet melalui facebook sebanyak 17 orang $(56,7 \%)$, sebagian besar mendapatkan informasi dari tenaga kesehatan melalui bidan sebanyak 14 orang (46,7\%), sebagian besar mendapatkan informasi dari keluarga melalui suami sebanyak 19 orang $(63,3 \%)$.

Berdasarkan tabel 2 diketahui dari 30 ibu hamil sebagian besar memiliki pengetahuan baik sebanyak 56,7\%, Menurut sumber informasi televisi ibu hamil yang memiliki pengetahuan baik yaitu mendapat sumber informasi dari berita dimana berita merupakan sarana penyampaian pesan tentang segala peristiwa aktual yang dibutuhkan banyak orang. Sedangkan ibu hamil yang memiliki pengetahuan kurang mendapat sumber informasi dari film yang mana dalam sebuah film hanya menampilkan drama saja dan hanya sedikit pesan yang disampaikan terutama mengenai kesehatan.

Hal ini sesuai dengan penelitian Dewi 2020 menyebutkan bahwa mayoritas ibu hamil memiliki pengetahuan baik. Hal ini disebabkan karena ketidakmampuan ibu hamil dalam memahami hal-hal yang berkaitan dengan covid-19 dan pencegahannya. Faktor lain yaitu karena ibu hamil kurang mendapatkan informasi dari berbagai media termasuk jarang menonton televisi tentang berita kesehatan (Dewi et al., 2020). 
JOURNAL OF MIDWIFERY CARE :

VOL. 02 No. 01, DESEMBER 2021

DOI : $\underline{10.34305 / J M C . V 2 I 01.346}$

Hasil menunjukkan bahwa dari $30 \mathrm{ibu}$ hamil yang mendapatkan sumber informasi dari internet sebagian besar memiliki pengetahuan baik yaitu 13 orang atau $76,5 \%$ mendapat sumber informasi dari facebook.

Sejalan dengan penelitian Sulistianingsih (2018), didapatkan sumber informasi berdasarkan pengetahuan ibu. Pada ibu hamil yang berpengetahuan baik, sumber informasi didapatkan dari penggunaan internet $(46,4 \%)$. Pada ibu berpengetahuan cukup didapatkan sebagian besar ibu mendapatkan sumber informasi dari penggunaan internet (47,2\%). Pada ibu yang berpengetahuan kurang didapatkan sumber informasi dari penggunaan internet (73,9\%). Hasil tersebut membuktikan bahwa internet sangat berpengaruh pada pengetahuan ibu hamil di jaman sekarang.

Pada sumber informasi tenaga kesehatan didapatkan hasil bahwa dari 30 ibu hamil, 12 diantaranya mendapat sumber informasi dari dokter dan 11 orang atau 91,7\% memiliki pengetahuan baik. Ibu hamil yang memiliki pengetahuan baik hampir seluruhnya mendapat informasi dari seorang bidan, karena bidan bisa disebut juga sahabat para perempuan karena bekerja sebagai mitra perempuan untuk memberikan dukungan, asuhan dan
Ciptaan disebarluaskan di bawah

Lisensi Creative Commons Atribusi-

NonKomersial-BerbagiSerupa 4.0 Internasional.

nasihat selama masa hamil termasuk dalam upaya pencegahan penularan covid-19, masa persalinan dan masa nifas, memfasilitasi dan memimpin persalinan atas tanggung jawab sendiri dan memberikan asuhan kepada bayi baru lahir, dan bayi.

Tujuan utama dari komunikasi kesehatan adalah untuk mempengaruhi orang maupun kelompok masyarakat agar mampu meningkatkan kondisi kesehatan mereka dengan berbagi informasi kesehatan yang akurat. Disinilah komunikator (tenaga kesehatan) memiliki peran yang krusial. Edukasi dilakukan kepada kepala desa, aparat keamanan, dan tokoh masyarakat yang diharapkan akan menjadi komunikator-komunikator yang dapat memberikan informasi yang akurat kepada masyarakat luas. Pesan Dalam Upaya Pencegahan Penyebaran Covid-19 (Teguh \& Arviana, 2020).

Menurut tabel 5 diketahui bahwa dari 30 ibu hamil 19 orang diantaranya mendapatkan sumber informasi dari suami dan 16 orang atau $84 \%$ diantaranya memiliki pengetahuan yang baik, sedangkan dari 9 orang ibu hamil yang mendapatkan pengetahuan dari orangtua 6 orang atau $66,7 \%$ diantaranya mendapatkan pengetahuan baik pula. 
JOURNAL OF MIDWIFERY CARE :

VOL. 02 No. 01, DESEMBER 2021

DOI : $\underline{10.34305 / J M C . V 2 I 01.346}$

Untuk ibu hamil yang mendapat informasi dari saudara seluruhnya ada 2 orang atau $100 \%$ memiliki pengetahuan baik. Ibu hamil yang mendapat informasi dari suami mendapati jumlah terbanyak karena suami merupakan orang terdekat pertama bagi seorang istri, setelah menikah seluruh kehidupan istri merupakan tanggungjawab suami termasuk dalam hal pengetahuan dan pencegahan penularan covid-19.

Di masa Pandemi Covid-19, Peran keluarga sangat dibutuhkan terutama suami. Dengan ungkapan lain, keluarga dapat diimplifikasikan sebagai konteks sosial primer dalam mempromosikan kesehatan dan pencegahan penyakit dalam mencegah persebaran dari berbagai jenis penyakit termasuk covid-19 (Saefullah, 2020).

Menurut penelitian (Tjiptasari \& Ridwan, 2017) Sebagian besar ibu hamil memperoleh sumber informasi dari tenaga kesehatan saat memberikan konseling 33,3\% kemudian, keluarga 6,9\%, Buku KIA 3,3\% dan sisanya dari media cetak 2,3\%. Dari penelitian tersebut membuktikan bahwa peran keluarga sangatlah penting untuk menambah wawasan dan pengetahuan ibu hamil.

Hasil penelitian (Cahyaningrum, 2021), didapat hasil bahwa responden yang
Ciptaan disebarluaskan di bawah

Lisensi Creative Commons Atribusi-

NonKomersial-BerbagiSerupa 4.0 Internasional

mendapatkan informasi dari media cetak sebanyak $3(14,3 \%)$ mempunyai perilaku kurang terhadap pencegahan penularan Covid-19 dan 12 (85,7\%) yang berperilaku baik Hasil penelitian ini sejalan dengan teori Bakir dalam (Iswanto \& Sulistyowati, 2018) menjelaskan informasi memiliki ciri utama berupa konektivitas dengan internet. Seseorang akan mencari informasi apabila ia memerlukan jawaban pertanyaan atau ingin mencari fakta atas suatu keadaan. Pencarian informasi lambat laun berubah menjadi kebutuhan.

\section{Kesimpulan}

Gambaran pengetahuan ibu hamil tentang pentingnya melindungi diri dalam masa AKB di era new normal covid-19 berdasarkan sumber informasi di Posyandu Mawar diketahui bahwa dari 30 ibu hamil sebagian besar memiliki pengetahuan baik sebanyak 17 orang (56,7\%). Sebagian besar ibu hamil mendapatkan informasi dari televisi melalui berita sebanyak 18 orang $(60,0 \%)$ dan 15 orang diantaranya memiliki pengetahuan baik.

Sebagian besar ibu hamil mendapatkan informasi dari internet melalui facebook sebanyak 17 orang $(56,7 \%)$ dan 13 diantaranya memiliki 
JOURNAL OF MIDWIFERY CARE :

VOL. 02 No. 01, DESEMBER 2021

DOI : $\underline{10.34305 / J M C . V 2 I 01.346}$

pengetahuan baik. Sebagian besar ibu hamil mendapatkan informasi dari tenaga kesehatan melalui bidan sebanyak 14 orang $(46,7 \%)$ dan 12 diantaranya memiliki pengetahuan baik. Sebagian besar ibu hamil mendapatkan informasi dari keluarga melalui suami yaitu sebanyak 19 orang $(63,3 \%)$ dan 16 diantaranya memiliki pengetahuan baik.

\section{Saran}

1. Bagi Ibu Hamil

Diharapkan bagi ibu hamil yang sudah memiliki pengetahuan baik dapat berbagi pengetahuan kepada ibu hamil lain atau atau masyarakat lain tentang cara perlindungan diri dalam masa AKB Covid-19.

2. Bagi Posyandu Mawar Desa Sukaharja

Diharapkan kader posyandu berkolaborasi dengan bidan desa dan petugas kesehatan lainnya agar lebih sering memberikan penyuluhan terkait dengan tata cara perlindungan diri dalam masa $\mathrm{AKB}$ Covid-19.

3. Bagi Program Studi

Menjadi dasar untuk menambah bahan kajian tentang perlindungan diri dalam masa $\mathrm{AKB}$ di era new
Ciptaan disebarluaskan di bawah

Lisensi Creative Commons Atribusi-

NonKomersial-BerbagiSerupa 4.0 Internasional.

normal Covid-19 di media sosial dan melakukan penyuluhan kepada siswa - siswa di sekolah.

\section{Referensi}

Cahyaningrum, F. (2021). Gambaran Pengetahuan Dan Sikap Ibu Hamil Terhadap Pencegahan Covid 19. MIKIA: Mimbar Ilmiah Kesehatan Ibu Dan Anak (Maternal and Neonatal Health Journal), 37-44.

Dewi, R., Widowati, R., \& Indrayani, T. (2020). Pengetahuan dan sikap ibu hamil trimester III terhadap pencegahan Covid-19. Health Information: Jurnal Penelitian, 12(2), 131-141.

Iswanto, R., \& Sulistyowati, S. (2018). Prospek Pusat Informasi dan Perpustakaan dalam Perkembangan Information And Communication Technology (ICT): Tinjauan Komprehensif Nilai Filosofi Ilmu Informasi dan Perpustakaan. Tik Ilmeu: Jurnal Ilmu Perpustakaan Dan Informasi, 2(1), 55-70.

Komite Penanganan Covid-19. (2020). Data Sebaran Covid-19. https://covid.19.go.id

Saefullah, R. (2020). Subang Enter the Covid-19 Low Risk Zone: Economic News Portal. https://www.wartaekonomi.co.id/read 295894/alhamdulillah-subang-masukzona-risiko-rendah-covid-19

Teguh, M., \& Arviana, S. (2020). Upaya Komunikasi Kesehatan di Puskesmas Trenggalek Dalam Pencegahan Penyebaran COVID-19. 
JOURNAL OF MIDWIFERY CARE :

VOL. 02 No. 01, DESEMBER 2021

DOI : $10.34305 /$ JMC.V2I01.346

Tjiptasari, F., \& Ridwan, M. M. (2017).

Kebutuhan Informasi Mahasiswa

Fakultas

Ilmu

Pendidikan
Ciptaan disebarluaskan di bawah Lisensi Creative Commons AtribusiNonKomersial-BerbagiSerupa 4.0 Internasional.

Perpustakaan FIP UNY. Pustakaloka, 9(1), 57-67. 